\title{
Comparative Study of Some Synthetic and Herbal Pyrethroids on Leuttuce Contents in Saudi Arabia
}

\author{
Nada Hamad Abdallah El-Khoshiban \\ Departement of Biology, College of Sciences and Arts at Buraidah, Qassim University, P.O. Box 5380, SaudiArabia.
}

\begin{abstract}
Three synthetic and one botanical pyrethroids were evaluated during growing of lettuce using the recommended concentrations as suggested by the Saudi Ministry of Agriculture. We conducted experiments to examine the impact of multiple insecticides and fertilizer applications on lettuce photosynthesis and yield. Those pesticides named deltametherin, azadirechtin (herbal), fury ( EW-10\% zeta-cyprmethrin) and biotrin (botanical). The objectives of the study were comparable (chlorophyll, carbohydrates, proline contents ) under applications of organic fertilizer, chemical and herbal pesticides and also to assess the variations of these parameters at two different doses for 3 months.Tested pyrethroids were compared, the data revealed that the high dose of biotrin alone or combined with fertilizer was the most effective treatment resulted in a more increment in chlorophyll and total sugar and proline contents, while high dose only induced significant decrease in carotien and soluble sugar. Zeta- cypermethrin came in the second order with the average of 56\% increased in sugar( $39 \%$ ), and chlorophyll (36\%). High dose of deltametherin and azadirechtin were the least effective treatment. In the present study, biotrin alone or with fertilizer is recommended to be used for controlling the pest in lettuce because of its excellent performance with minimum side effects on the plant contents. However, consideration the long term effects of chemical pesticides on the soil, we recommend that biotrin with organic fertilizer should be considered for incorporation in soils to improve the levels of chlorophyll in lettuce plants and preferably harvesting should be done for animal consumption. Conclusion: These studies suggest that lettuce photosynthesis may be susceptible to some insecticides at the seedling stage. Consequently, we found that biorational insecticides introduced to manage insect pests in lettuce, have no influence on lettuce physiology at the seedling stage.
\end{abstract}

Keywords: pyrethroides,lettuce,chlorophyll,organic fertilizer,azadirechtin,biotrin

\section{Introduction}

The increased use of insecticides and their impacts on the environment have become a matter of considerable concern in recent decades. The use of pesticides, especially synthetic ones, is suggested to be replaced by compensatory substances that exert a lower risk to the environment (1).

Insecticides are used extensively on lettuce, Lactuca sativa L., grown in Saudi Arabia because of heavy insect pressure that can potentially reduce lettuce productivity. One of the major concerns related to extensive insecticide applications in lettuce is the potential subtle impact of insecticides that may reduce lettuce photosynthesis and yield (2). Herbicides have been used widely and intensively in agricultural areas around the globe to enhance crop yield. However, many biocides are causing serious environmental problems and may possess critical risks on treating agricultural crops ( 3 ). In conventional agriculture, lettuce crops receive large amounts of pesticides to meet stringent industrial specifications and market requirements. Pesticides are used on lettuce to ensure high-yielding, attractive products free from foreign bodies and damage. Pesticide reduction is a major challenge for lettuce growers in this context. The efficacy of each strategy for pest and pathogen control, as well as lettuce yield and quality, were assessed and compared. Globally, abiotic damage was less important than abiotic damage, and resulted in low commercial losses under all strategies. Therefore the performances of intermediate and low-input crop protection strategies were consistent with market expectations, and possible improvements are discussed( 4). The study of (5) provides a methodology and landmarks for the design and dissemination of cropping systems targeted to leafy vegetables and less dependent on chemical control of pests and pathogens.
Agriculture found that one-fifth of organic lettuces actually tested positive for spinosad, a naturally occurring soil bacterium that's manufactured by chemical and is one of about 40 synthetic chemicals permitted under the USDA's National Organic Standards. All things considered, the responsible use of synthetic herbicides might be less of a risk than the irresponsible use of spinosad.(6) .

Major economic yield losses can occur in lettuce from insect pests such as the beet armyworm.

In crops such as lettuce, which receive multiple insecticide spray applications in a season, there is a concern that insecticides may impact crop physiology and yield. Previous work demonstrated that methyl parathion and permethrin significantly reduced lettuce photosynthesis and yield (7) .

New insecticides are being introduced to manage lettuce insect pests. However, the impact of the new insecticides on plant physiology has not been reported. Some of these insecticides are claimed to have translaminar activity, with the compound entering the leaf cuticle to form a reservoir of active ingredient. If these compounds enter the leaf cuticle . they may also impact plant gas exchange processes and alter crop yield (4).

Insecticides usually are used as research tools to establish insect pest density and crop yield loss relationships in studies designed to develop economic injury levels (8).

Studies that examined the impact of some organophosophate insecticides on lettuce photosynthesis, were conducted over $15 \mathrm{yr}$ ago. Some of those insecticides such as methyl parathion, are no longer used in lettuce to control insect pests . Consequently, we conducted field and greenhouse 


\section{International Journal of Science and Research (IJSR) \\ ISSN (Online): 2319-7064}

Index Copernicus Value (2013): 6.14 | Impact Factor (2015): 6.391

experiments to examine the impact of selected insecticides and surfactants on lettuce physiology and yield (9).

The insecticides used in this study were chosen to represent the major classes of insecticides (deltametherin, azadirechtin, fury and biotrin ). The efficacy biotrin as biopesticide was evaluated on Ceratitis capitata under laboratory conditions. In addition, the effects of the tested compounds on the physiological content of lettuce (10) . Proteins were involved in ion homeostasis, protein turnover and signaling, protein folding, cell wall components, carbohydrate and energy metabolism (11). After more than 70 years of chemical pesticide use, modern agriculture is increasingly using biological control products. However, a good knowledge of the limitations of a new technique often provides greater sustain ability (12).

\section{Materials and Methods}

\section{Plant experimental methods}

\section{Chemicals:}

1) Deltametherin from Sulphur Mills Limited Company at low dose ( 5 / L ) and high dose ( $7.5 / \mathrm{L})$.

2) Azadirachtin (EC) 10 grams/liters acquired from Astrachem Company, Astra Industrial Group. Low and high doses are used at $0.25 \mathrm{ml}$ per 100 liters of water and $250 \mathrm{ml}$ per 100 liters of water respectively.

3) Fury (zeta-cypermethrin ) :fury EC\%w/w from Mobideco Company at low dose $(0.5 / \mathrm{L})$ and high dose $(1 / \mathrm{L} \%)$.

4) Biotrin (Matrine $0.36 \%$ ). Beijing mul Tigress at low dose $1 / \mathrm{L})$ and high dose (5/L).

5) Acadian, a fertilizer, is used at a dose level of $100 \mathrm{ml}$ per liter. Natural content was acquired from Acadian Agrich Company, Canada.

\section{Methods \\ Lettuce plants were used for testing and segmented in six groups : \\ Group I: Untreated plant (normal control group). \\ Group II: Lettuce exposed to organic fertilizer only \\ Group III: Lettuce exposed to low concentration of deltametherin, azadirachtin, zeta-cypermetrin and biotrin . \\ Group IV: Lettuce exposed to high concentration of deltametherin, azadirachtin, zeta-cypermetrin and biotrin . \\ Group V: Lettuce exposed to low concentration of deltametherin, azadirachtin, zeta-cypermetrin and biotrin and mixed with organic fertilizer. \\ Group VI: Lettuce exposed to high concentration of deltametherin, azadirachtin, zeta-cypermetrin and biotrin and mixed with organic fertilizer}

This study was designed to investigate potential impact of deltametherin, azadirachtin, zeta-cypermetrin and biotrin at different levels of concentrations low, high, and organic fertilizers in lettuce plant. The samples of the study will be gathered at different stages of plant growth. Further, when concluding the experimental period, which is three months, sample extracted from plant will be studied for chemical estimations. The estimations are:

- Photosynthetic pigments ( chlorophyll A and chlorophyll B, carotien )according to the study method of (13) by using Spectrophotometer model namely Spectro UV-VIS RS.

- Soluble sugars by using Spectrophotometer

- Total sugars according to the study method of (14) by using Spectrophotometer

- Proline content, which is amino acid according to the method of (15) based on the usage of Spectrophotometer

\section{Statistical analysis}

The generated data were analyzed through 'Statistical Package for Social Sciences (SPSS), version 16' software program. The analysis of covariance or one way ANOVA was applied to identify differences in mean between treated groups and control groups. Similar application was also done to identify mean difference between fertilizer treated groups against all treated groups. The mean difference is significant at $\mathrm{P}<0.05$.

\section{Results}

The results of the present study revealed that chlorophyll A and B levels significantly increased in fertilizer and low dose deltametherin treated group versus normal group, while in group IV and $\mathrm{V}$ its levels significantly decreased. As regards to carbohydrate content ( total soluble sugar \& total sugar ) low and high dose of deltamethrin and combined treatment with fertilizer induced significant increased in total soluble sugar compared with normal treated group Proline content in lettuce plant increased in fertilizer treated group while it decreased in plant exposed to low dose of deltametherin compared with fertilizer treated group only .Combined treatment with both doses of deltametherin and fertilizer ( group V and VI ) leading to significant decreased in proline content vesus the fertilizer group ( group II) .

As regards to azadirechtin treatment, chlorophyll A and chlorophyll B significantly increased in fertilizer treated groups, while low and high dose of azadirachtin induced significant decrease in chlorophyll A and chlorophyll B content when compared with fertilizer treated group. High dose of azadirachtin and low dose with fertilizer treated groups induced significant decrease in carotein content. This study exhibits that low and high compressed with significant increase in total and soluble sugar content, compared with normal treated group. Synchronized treatment of fertilizer with azadirachtin in low and high dose showed significant increase in total and soluble content in contrast to normal group. However, there is an exception of significant decrease in total sugar with high doses of azadirachtin. Proline contents significantly increased in fertilizer treated group, while contents decrease significantly in other treated groups compared with normal.

Leuttuce treated with zeta-cypermethrin ( fury) produced significant increased in chlorophyll ( A) and ( B) contents while there levels significantly decrease in all treated groups .Carotein levels decreased with fertilizer and zetacypermetrin treated groups. As regards to carbohydrate contents in lettuce treated plant,total sugar and soluble sugar decreased significantly in all treated groups .Proline concentrations increased in fertilizer and with high dose zeta-cypermetrin treated groups, while its level start to decrease in the group treated with low dose of zeta- 


\section{International Journal of Science and Research (IJSR) \\ ISSN (Online): 2319-7064 \\ Index Copernicus Value (2013): 6.14 | Impact Factor (2015): 6.391}

cypermetrin and fertilizer but the level start to increase with high dose with fertilizer .

Biotrin treatment, increased content of chlorophyll(A) and (B) in fertilizer and all treated groups except low dose with fertilizer treated group .Carotein content decreased significantly in all treated groups .
This result indicates that biotrin and fury alone and with fertilizer decreased the oxidative stress in leuttuce plant than other insecticides. Carbohydrates start to decrease in low doses of biotrin while increasing with high dose, but with the addition of fertilizer to both doses of biotrin it start to decrease . Proline start to increase in fertilizer and high dose of biotrin while decreased with low dose and both dose with fertilizer treated groups.

Table 1: Effects of fertilizer,deltamethrin, azadirechtin, fury and biotrin alone or combined with fertilizer on chlorophyll (A) content in different treated groups.

\begin{tabular}{|c|c|c|c|c|c|c|c|c|}
\hline Parameter Group & \multicolumn{2}{|c|}{ Deltametherin } & \multicolumn{2}{|c|}{ Azadirechtin } & \multicolumn{2}{|c|}{ Fury } & \multicolumn{2}{|c|}{ Biotrin } \\
\hline Group 1 & $\begin{array}{r}\text { Mean } \pm \text { S.E. } \\
7.34 \pm .360\end{array}$ & $\begin{array}{c}\text { significant } \\
\text { test } \\
----\end{array}$ & $\begin{array}{r}\text { Mean } \pm \text { S.E. } \\
7.19 \pm .128\end{array}$ & $\begin{array}{c}\text { significant } \\
\text { test } \\
----\end{array}$ & $\begin{array}{l}\text { Mean } \pm \text { S.E. } \\
9.15 \pm .283\end{array}$ & $\begin{array}{c}\text { significant } \\
\text { test } \\
---\end{array}$ & $\begin{array}{c}\text { Mean } \pm \text { S.E. } \\
8.67 \pm .412\end{array}$ & $\begin{array}{c}\text { significant } \\
\text { test } \\
---\end{array}$ \\
\hline Group 11 & $9.91 \pm .360$ & $0.000 *$ & $9.29 \pm .363$ & $0.000 *$ & $10.41 \pm .245$ & $0.000 *$ & $10.43 \pm .245$ & $0.000 *$ \\
\hline Group 111 & $9.40 \pm .330$ & $0.000 *$ & $6.64 \pm .204$ & 0.188 & $5.85 \pm .084$ & $0.000 *$ & $8.88 \pm .195$ & .015 \\
\hline Group 1V & $4.28 \pm .243$ & $0.000 *$ & $7.56 \pm .511$ & 0.374 & $4.89 \pm .197$ & $0.000 *$ & $9.54 \pm .353$ & $0.000 *$ \\
\hline Group V & $5.94 \pm .360$ & $0.000 *$ & $6.92 \pm .172$ & 0.524 & $6.35 \pm .135$ & $0.000 *$ & $8.56 \pm .591$ & 0.324 \\
\hline Group VI & $7.98 \pm .312$ & $0.001 *$ & $6.77 \pm .152$ & 0.317 & $5.51 \pm .130$ & 0.000 * & $10.29 \pm .088$ & $0.000 *$ \\
\hline
\end{tabular}

The mean difference is significant at $\mathrm{P}<0.05(*)$

Significant, compared with normal control groups

Table 2: Effects of fertilizer,deltamethrin, azadirechtin,fury and biotrin alone or combined with fertilizer on Chlorophyll ( B) content in different treated groups

\begin{tabular}{|c|c|c|c|c|c|c|c|c|}
\hline \multirow{2}{*}{ Parameter Group } & \multicolumn{2}{|c|}{ Deltamethrin } & \multicolumn{2}{c|}{ Azadirechtin } & \multicolumn{2}{c|}{ Fury } & \multicolumn{2}{c|}{ Biotrin } \\
\cline { 2 - 9 } & Mean \pm S.E. & significant test & Mean \pm S.E. & significant test & Mean \pm S.E. & significant test & Mean \pm S.E. & significant test \\
\hline Group 1 & $3.72 \pm .26259$ & ----- & $3.38 \pm .124$ & - & $5.50 \pm .201$ & ---- & $5.44 \pm .656$ & ---- \\
\hline Group 11 & $5.69 \pm .26259$ & $0.000^{*}$ & $5.43 \pm .157$ & $0.000^{*}$ & $6.81 \pm .142$ & $0.000^{*}$ & $6.81 \pm .142$ & $0.000^{*}$ \\
\hline Group 111 & $5.55 \pm .26259$ & $0.000^{*}$ & $3.02 \pm .306$ & 0.23 & $3.85 \pm .125$ & $0.000^{*}$ & $5.75 \pm .344$ & $0.000^{*}$ \\
\hline Group 1V & $1.80 \pm .26259$ & $0.000^{*}$ & $3.37 \pm .154$ & 0.973 & $3.18 \pm .157$ & $0.000^{*}$ & $9.03 \pm .242$ & $0.000^{*}$ \\
\hline Group V & $3.57 \pm .26259$ & 0.564 & $4.31 \pm .163$ & $0.003^{*}$ & $4.40 \pm .197$ & $0.000^{*}$ & $6.01 \pm .319$ & $0.000^{*}$ \\
\hline Group VI & $4.66 \pm .26259$ & $0.000^{*}$ & $2.92 \pm .257$ & 0.121 & $4.52 \pm .205$ & $0.000^{*}$ & $8.34 \pm 0.345$ & $0.000^{*}$ \\
\hline
\end{tabular}

The mean difference is significant at $\mathrm{P}<0.05\left(^{*}\right)$

Significant, compared with normal control group

Table 3: Effects of fertilizer,deltamethrin, azadirechtin,fury and biotrin alone or combined with fertilizer on carotein content in different treated groups.

\begin{tabular}{|c|c|c|c|c|c|c|c|c|}
\hline \multirow{2}{*}{$\begin{array}{c}\text { Parameter } \\
\text { Group }\end{array}$} & \multicolumn{2}{|c|}{ Deltamethrin } & \multicolumn{2}{c|}{ Azadirechtin } & \multicolumn{2}{c|}{ Fury } & \multicolumn{2}{c|}{ Biotrin } \\
\cline { 2 - 10 } & Mean \pm S.E. & significant test & Mean \pm S.E. & significant test & Mean \pm S.E. & significant test & Mean \pm S.E. & significant test \\
\hline Group 1 & $1.65 \pm .100$ & --- & $1.55 \pm .039$ & ---- & $1.57 \pm .037$ & --- & $1.63 \pm .213$ & --- \\
\hline Group 11 & $1.40 \pm .106$ & 0.303 & $1.36 \pm .050$ & 0.139 & $1.35 \pm .038$ & $0.000^{*}$ & $1.35 \pm .038$ & $0.000^{*}$ \\
\hline Group 111 & $1.34 \pm .152$ & 0.045 & $1.68 \pm .163$ & 0.325 & $1.33 \pm .055$ & 0.19 & $0.45 \pm .109$ & 0.19 \\
\hline Group 1V & $1.19 \pm .088$ & $0.004^{*}$ & $1.11 \pm .040$ & $0.001^{*}$ & $1.65 \pm .041$ & $0.000^{*}$ & $0.46 \pm .112$ & $0.000^{*}$ \\
\hline Group V & $1.04 \pm 0.869$ & $0.000^{*}$ & $0.75 \pm .108$ & $0.000^{*}$ & $1.23 \pm .049$ & $0.000^{*}$ & $1.54 \pm .089$ & $0.000^{*}$ \\
\hline Group VI & $1.18 \pm .077$ & $0.000^{*}$ & $1.53 \pm .068$ & 0.859 & $1.50 \pm .037$ & 0.1 & $0.34 \pm .064$ & $0.000^{*}$ \\
\hline
\end{tabular}

The mean difference is significant at $\mathrm{P}<0.05\left(^{*}\right)$

Significant, compared with normal control group.

Table 4: Effects of fertilizer,deltamethrin, azadirechtin,fury and biotrin alone or combined with fertilizer on soluble sugars $(\mathrm{mg} / \mathrm{dl})$ in different treated groups

\begin{tabular}{|c|c|c|c|c|c|c|c|c|}
\hline \multirow[b]{2}{*}{$\begin{array}{l}\text { Parameter } \\
\text { Group }\end{array}$} & \multicolumn{2}{|c|}{ Deltamethrin } & \multicolumn{2}{|c|}{ Azadirechtin } & \multicolumn{2}{|c|}{ Fury } & \multicolumn{2}{|c|}{ Biotrin } \\
\hline & Mean \pm S.E. & significant test & Mean \pm S.E. & significant test & Mean \pm S.E. & significant test & Mean \pm S.E. & $\begin{array}{c}\text { significant } \\
\text { test }\end{array}$ \\
\hline Group 1 & $5143.3 \pm 1.21$ & $0.000 *$ & $5196.37 \pm 86.52$ & ---- & $10499.61 \pm 32.97$ & ---- & $10490.65 \pm 39.43$ & ---- \\
\hline Group 11 & $5078.3 \pm 32.66$ & 938 & $5984.42 \pm 21.65$ & $0.000 *$ & $12020.72 \pm 1.47$ & $0.000 *$ & $1257.42 \pm 1.47$ & 0.174 \\
\hline Group 111 & $1030.0 \pm 18.42$ & 0.951 & $5940.77 \pm 16.17$ & $0.000 *$ & $6432.35 \pm 1.51$ & $0.000 *$ & $10491.66 \pm 1.85$ & $0.000 *$ \\
\hline Group 1V & $7830.0 \pm 38.05$ & $0.000 *$ & $5965.55 \pm 30.30$ & $0.000 *$ & $35354.11 \pm 8.31$ & $0.000 *$ & $8828.83 \pm 3.13$ & $0.000^{*}$ \\
\hline Group V & $5681.7 \pm 11.80$ & 0.923 & $5580.05 \pm 11.89$ & $0.000 *$ & $998.55 \pm 20.96$ & $0.000 *$ & $10690.01 \pm 2.01$ & $0.000 *$ \\
\hline Group VI & $7423.3 \pm 14.58$ & 0.818 & $5754.86 \pm 16.62$ & $0.000 *$ & $892.43 \pm 34.01$ & $0.000 *$ & $3954.50 \pm 49.21$ & $0.000^{*}$ \\
\hline
\end{tabular}

The mean difference is significant at $\mathrm{P}<0.05(*)$

Significant, compared with normal control group.

\section{Volume 5 Issue 5, May 2016} www.ijsr.net 


\section{International Journal of Science and Research (IJSR) \\ ISSN (Online): 2319-7064 \\ Index Copernicus Value (2013): 6.14 | Impact Factor (2015): 6.391}

Table 5: Effects of fertilizer,deltamethrin, azadirechtin,fury and biotrin alone or combined with fertilizer on total sugars $(\mathrm{mg} / \mathrm{dl})$ in different treated groups .

\begin{tabular}{|c|c|c|c|c|c|c|c|c|}
\hline \multirow{2}{*}{$\begin{array}{c}\text { Parameter } \\
\text { Group }\end{array}$} & \multicolumn{2}{|c}{ Deltamethrin } & \multicolumn{2}{c|}{ Azadirechtin } & \multicolumn{2}{c|}{ Fury } & \multicolumn{2}{c|}{ Biotrin } \\
\cline { 2 - 11 } & Mean \pm S.E. & significant test & Mean \pm S.E. & significant test & Mean \pm S.E. & significant test & Mean \pm S.E. & significant test \\
\hline Group 1 & $5343.6 \pm 1.23$ & --- & $4918.6 \pm 20.52$ & --- & $16794.2 \pm 23.89$ & --- & $16874.2 \pm 39.43$ & ---- \\
\hline Group 11 & $5732.66 \pm 1.61$ & 0.847 & $5670.0 \pm 28.75$ & $0.000^{*}$ & $17585.5 \pm 1.16$ & $0.000^{*}$ & $17585.49 \pm 1.16$ & $0.000^{*}$ \\
\hline Group 111 & $5037.6 \pm 47.36$ & $0.000^{*}$ & $7532.9 \pm 10.28$ & $0.000^{*}$ & $655.9 \pm 19.39$ & $0.000^{*}$ & $10482.15 \pm 1.85$ & 0.3 \\
\hline Group 1V & $1514.5 \pm .53$ & 0.117 & $7231.4 \pm 21.03$ & $0.000^{*}$ & $1267.7 \pm 47.19$ & $0.000^{*}$ & $55940.26 \pm 3.13$ & $0.000^{*}$ \\
\hline Group V & $4860.6 \pm 3.3$ & $0.000^{*}$ & $7044.3 \pm 22.53$ & $0.000^{*}$ & $1033.6 \pm 15.46$ & $0.000^{*}$ & $8444.90 \pm 2.01$ & $0.000^{*}$ \\
\hline Group VI & $4197.4 \pm .47$ & $0.001^{*}$ & $1276.4 \pm 1.01$ & $0.000^{*}$ & $1036.5 \pm 22.61$ & $0.000^{*}$ & $9861.47 \pm 49.21$ & 0.2 \\
\hline
\end{tabular}

The mean difference is significant at $\mathrm{P}<0.05\left(^{*}\right)$

Significant, compared with normal control group.

Table 6: Effects of fertilizer,deltamethrin, azadirechtin,fury and biotrin alone or combined with fertilizer on proline content in different treated groups.

\begin{tabular}{|c|c|c|c|c|c|c|c|c|}
\hline \multirow{2}{*}{$\begin{array}{c}\text { Parameter } \\
\text { Group }\end{array}$} & \multicolumn{2}{|c|}{ Deltamethrin } & \multicolumn{2}{c|}{ Azadirechtin } & \multicolumn{2}{c|}{ Fury } & \multicolumn{2}{c|}{ Biotrin } \\
\cline { 2 - 10 } & Mean \pm S.E. & significant test & Mean \pm S.E. & significant test & Mean \pm S.E. & significant test & Mean \pm S.E. & significant test \\
\hline Group 1 & $2.03 \pm 0.19$ & ---- & $1.94 \pm .17$ & ---- & $1.68 \pm .12$ & ---- & $4.18 \pm .15$ & --- \\
\hline Group 11 & $4.21 \pm 0.68$ & $0.000^{*}$ & $5.16 \pm .11$ & $0.000^{*}$ & $1.40 \pm .15$ & 0.174 & $1.40 \pm .146$ & $0.000^{*}$ \\
\hline Group 111 & $0.65 \pm .0 .06$ & $0.000^{*}$ & $0.67 \pm .01$ & $0.000^{*}$ & $1.92 \pm .04$ & $0.000^{*}$ & $6.13 \pm .14$ & $0.000^{*}$ \\
\hline Group 1V & $1.36 \pm 0.24$ & $0.000^{*}$ & $0.63 \pm .0016$ & $0.000^{*}$ & $5.34 \pm .14$ & $0.000^{*}$ & $8.07 \pm .19$ & $0.000^{*}$ \\
\hline Group V & $2.24 \pm 0.11$ & $0.000^{*}$ & $0.57 \pm .01$ & $0.000^{*}$ & $1.54 \pm .04$ & 0.102 & $6.59 \pm .31$ & $0.000^{*}$ \\
\hline Group VI & $1.15 \pm 0.13$ & $0.000^{*}$ & $0.54 \pm .02$ & $0.000^{*}$ & $5.16 \pm .21$ & $0.000^{*}$ & $3.32 \pm .13$ & $0.000^{*}$ \\
\hline
\end{tabular}

The mean difference is significant at $\mathrm{P}<0.05\left(^{*}\right)$

Significant, compared with normal control group.

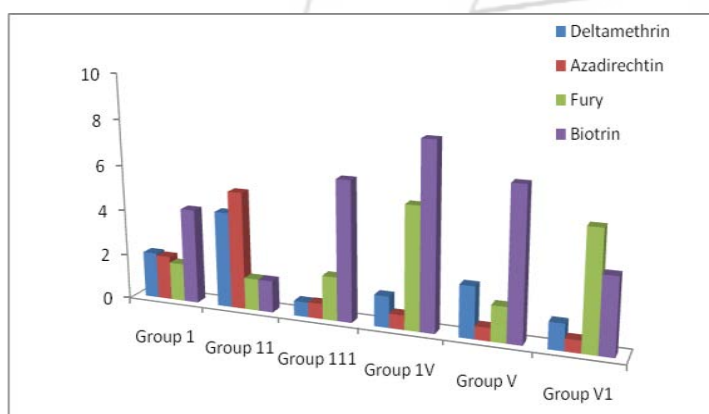

Figure 1: Effects of fertilizer, deltametherin,fury and biotrin alone or with fertilizer on chlorophyll (A) content in different treated groups

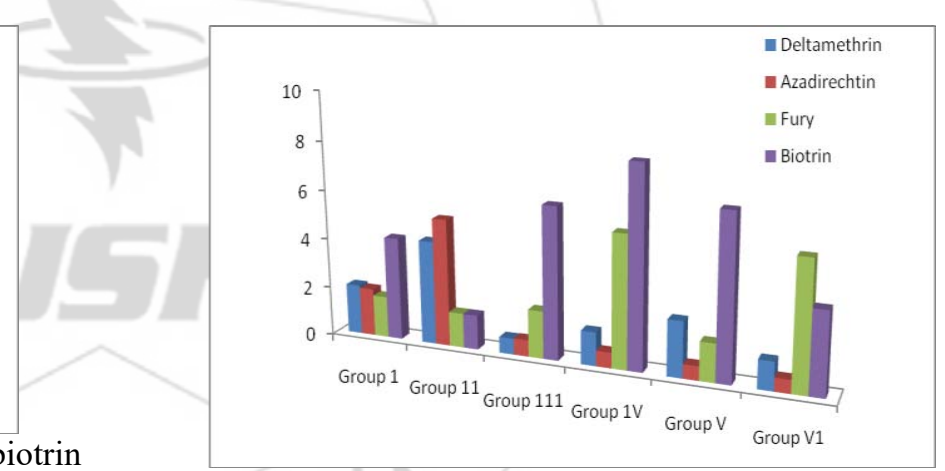

Figure 3: Effects of fertilizer, deltametherin,fury and biotrin

alone or with fertilizer on carotein content in different treated groups

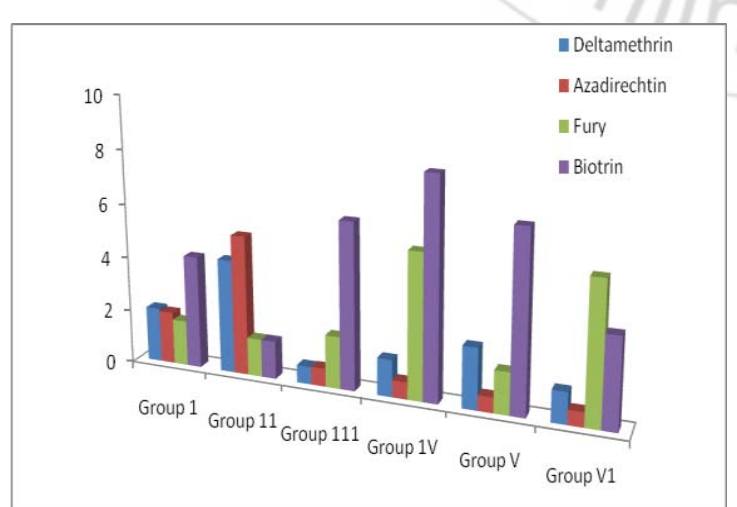

Figure 2: Effects of fertilizer, deltametherin,fury and biotrin alone or with fertilizer on chlorophyll (B) content in different treated groups

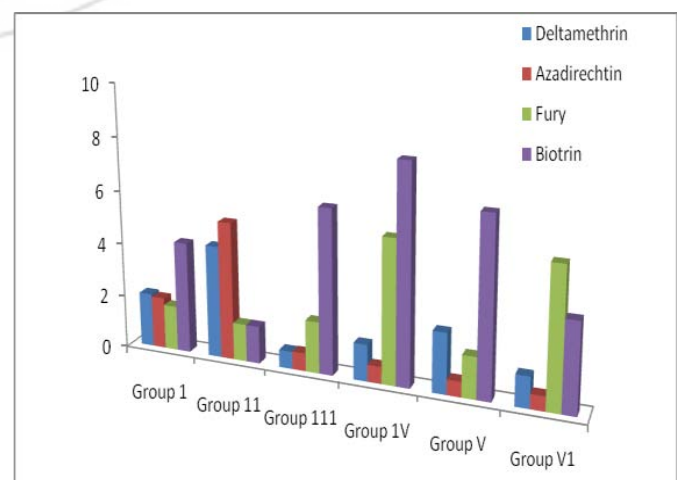

Figure 4: Effects of fertilizer,deltamethrin, azadirechtin,fury and biotrin alone or combined with fertilizer on soluble sugars $(\mathrm{mg} / \mathrm{dl})$ in different treated groups . 
International Journal of Science and Research (IJSR)

ISSN (Online): 2319-7064

Index Copernicus Value (2013): 6.14 | Impact Factor (2015): 6.391

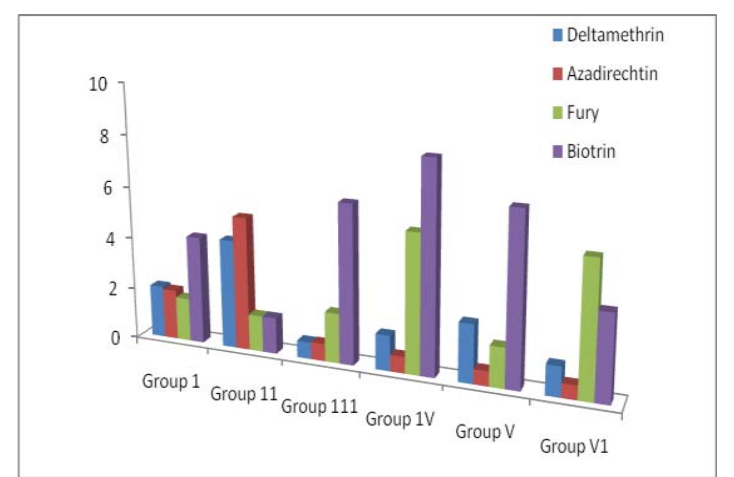

Figure 5: Effects of fertilizer,deltamethrin, azadirechtin,fury and biotrin alone or combined with fertilizer on total sugars $(\mathrm{mg} / \mathrm{dl})$ in different treated groups .

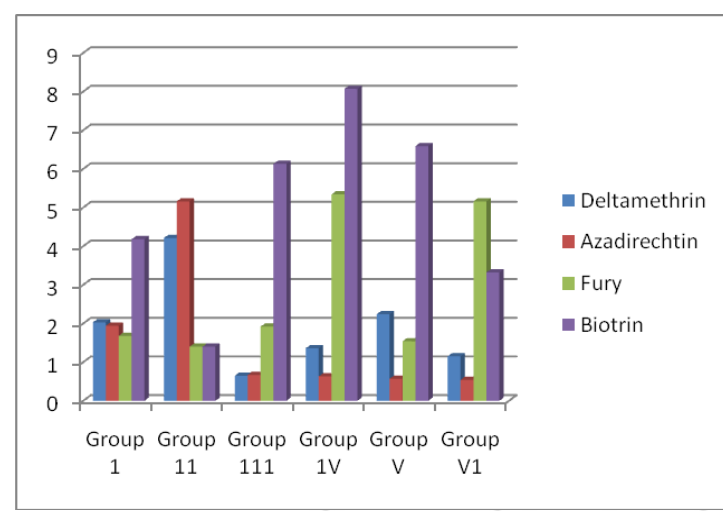

Figure 6: Effects of fertilizer,deltamethrin, azadirechtin,fury and biotrin alone or combined with fertilizer on proline content in different treated groups.

\section{Discussion}

Changes in lettuce physiology by insecticides may greatly depend on the growth stage of lettuce. The present study revealed that the high dose of biotrin alone or combined with fertilizer was the most effective treatment resulted in more increment in chlorophyll and total sugar and proline contents, while high dose only induced significant decrease in carotien and soluble sugar . Zeta- cypermethrin came in the second order with the average of $56 \%$ increased in sugar and chlorophyll. Azadirechtin was the least effective treatment. In the present study, biotrin alone or with fertilizer is recommended to be used for controlling the pest in lettuce because of its excellent performance with minimum side effects on the plant contents. However, consideration the long term effects of chemical pesticides on the soil, we recommend that biotrin with organic fertilizer should be considered for incorporation in soils to improve the levels of chlorophyll in lettuce plants and preferably harvesting should be done for animal consumption. However, these insecticides did not impact photosynthetic rates when lettuce began forming rosettes (8)

These results suggest that early in the season, lettuce gas exchange may be more susceptible to some insecticides and surfactant treatments than late in the season However, lettuce dry weight was not significantly altered. Insecticides and surfactant, despite the transient photosynthetic rate reductions at the seedling stage by some insecticides. Earlier studies documented reductions in lettuce photosynthesis and yield by methyl parathion( 16)
The subtle impact of insecticides and surfactants on plant physiology may greatly depend on the formulation and the rate and frequency of spray applications .Insecticides with an oil-based formulation usually interferes with plant gasexchange compared with other formulations (17). In addition the physical and chemical properties of ingredients (adjuvants) in a formulation may also be responsible for changes in plant physiology (18). Regarding the rate and frequency of spray applications, insecticides and may interfere with plant gas-exchange and yield a high rate (19). The current state of understanding, which concerns the role of charge recombination reactions in photo damage and photo protection. This mechanism is an important, but not exclusive, pathway of photodamage, and light-induced inactivation of water oxidation may occur in parallel with the singlet oxygen-dependent pathway (20). The main mechanism of photodamage induced by visible light appears to be mediated by acceptor side modifications, which develop under light intensity conditions when the capacity of light-independent photosynthetic processes limits the utilization of electrons produced in the initial photoreactions. This situation facilitates triplet chlorophyll formation and singlet oxygen production in the reaction center of PSII, which initiates the damage of electron transport components and protein structure.

Moreover, the repressed expression of photosynthesisrelated proteins and antioxidant enzymes led to the reduction of growth. Protein folding and degradation-related proteins and cell organization-related protein were up-regulated and played important roles in salt tolerance under severe salt stress (21).

Decreased vitro viability of the insect cell line was observed in the presence of parigidin-brl, consistent with in vivo insecticidal activity. Transmission electron microscopy and fluorescence microscopy of SF-9 cells after incubation with parigidin-brl or parigidin-brl-fluorescein isothiocyanate, respectively, revealed extensive cell lysis and swelling of cells, consistent with an insecticidal mechanism involving membrane disruption. This hypothesis was supported by in silico analyses, which suggested that parigidin-br1 is able to complex with cell lipids. Overall, the results suggest promise for the development of parigidin-br1 as a novel biopesticide (22).

Azadirechtin is now known to affect over 200 species of insect, by acting mainly as an antifeedant and growth disruptor, and as such it possesses considerable toxicity toward insects . Azadirachtin fulfills many of the criteria needed for a good insecticide. Azadirachtin is biodegradable (it degrades within 100 hours when exposed to light and water) and shows very low toxicity to mammals (. Some laboratory and field studies have found neem extracts to be compatible with biological control (23).

Thus, Neem is a broad spectrum pesticide and even compatible with most chemical pesticides. Neem works as an insecticide by intervening at several stages of the life of an insect. It may not kill the pests instantaneously but, incapacitate it in several other ways. Azadirechtin botanical insecticide acts in various ways like as antifeedant, as 


\section{International Journal of Science and Research (IJSR) \\ ISSN (Online): 2319-7064}

Index Copernicus Value (2013): 6.14 | Impact Factor (2015): 6.391

repellent, as growth inhibitor and also has ovi-position deterrent effect (24) .

Deltamethrin products are among the most popular and widely used insecticides in the world ${ }^{[}$and have become very popular with pest control operators and individuals in the United States. This material is a member of one of the safest classes of pesticides( synthetic pyrethroids). This pesticide is highly toxic to aquatic life, particularly fish, and therefore must be used with extreme caution around water(25) .

Cypermethrin is a synthetic, pyrethroid insecticide that is extremely effective against a wide range of insect pests. Because cypermethrin has a low Henry's Law Constant, except for some minor spray drift, it is not expected to be found in air. In soil and water, the major metabolites are PBA and DCVA via hydrolysis and photolysis, with the impurity 3-phenoxybenzaldehyde as a minor by product in water. Under aerobic conditions, the metabolites may break down further to produce $\mathrm{CO} 2$. The principal degradation route for cypermethrin in soil is hydrolysis of the ester linkage, leading to PBA, DCVA, and eventually CO2.

The persistence of the metabolites is unknown. Cypermethrin is fairly immobile in soil due to its strong affinity to bind to the organic matter. The metabolites, however, vary in their mobility from intermediate to mobile. Other factors effecting the degradation of cypermethrin in soils are $\mathrm{pH}$ and microbes. Higher $\mathrm{pH}$ increases adsorption, and cypermethrin degrades more slowly in sterile soils. In water, cypermethrin is relatively stable to hydrolysis and photolysis (26).

Cypermethrin hydrolyzes and photolyzes more quickly in a basic environment, where the chemical degraded much faster in river water versus distilled water. This suggests that naturally occurring substances enhance the breakdown of cypermethrin, and because of its high affinity for organic matter, cypermethrin readily adsorbs to suspended matter in natural waters. Cypermethrin is relatively non-toxic,it will metabolize to mono and disaccharide derivatives.. When applied topically to lettuce plants, cypermethrin is rapidly metabolized to $\alpha$-cyano-3-phenoxybenzyl alcohol. This type of application is not toxic to the plants, but is toxic tot he insects which feed on them (27). Soil and sediment are the main environmental reservoirs for cypermethrin, where nearly all of the compound ends up. Soil is also the compartment with the highest degradative potential for this chemical, especially those soils with high microbial activity. Sorption to soil and sediment has the net effect of reducing mobility and bioavailability of cypermethrin to sensitive species.(28) .

\section{References}

[1] Michelle F.S.,Pinto, Isabel .C.M. Fensterseifer, Ludovico Migliolo, Daniel A .Sousa and Octavio L . Franco (2012) .Identification and Structural Characterization of Novel Cyclotide with Activity against an Insect pest of Sugar Cane . The Journal of Biological Chemistry,287:134-147 .

[2] Bolhar-Nordenkampf, H. R ., S.P. Long, N .R. Bakerr . G. Oqquist, U.Schreibers, and E .G. Leehner ( 1989) .
Chlorophyll florescence as a probe of photosynthetic competence of leaves in the field : review of current instrumentation . Funct.Ecol . 3: 497-514.

[3] Hagner, Marleena ( 2013) . Potential of the slow pyrolysis products birch tar oil, wood vinegar and biovhar in sustainable plant protection : pesticidal effects, soil improvement and invironmental risks .http://urn.fi/URN:ISBN:978-952-10-9169-8 .

[4] Fikru J. Haile, David L. Kerns M. Richardson, and Leob G. Higley ( 2000) . Impact of Insecticides and Surfactant on Luttuce Physiology and Yaield .J. Entomol.93 (3) : 788-794 .

[5] Virginie Barriere, Francois Lecompte and FrancoiseLescourret (205) .Efficacy of pest and pathogen control, yield and quality of winter lettuce crops managed with reduced pesticide applications. European Journal of Agronomy, $71: 34-43$

[6] Kerns, D. L., M .E . Methron, J .C . Pulumbo, C .A .Sanchez, D .W . Still and N .A .Wilcox .(1999). Gudelines for head leuttuce production in Arizona. Univ. Ariz .Soop .Ezt . IPM Ser. 12 .

[7] Toscano, N . C., F. V . Sances, M . W.Johnson, and L. F . LaPre (1982) .Effect of various pesticides on leuttuce physiology and yield . J. Econ.Entomol .75 : 738-741 .

[8] Buntin, D .G . (1996) .Economic thresholds for pest management, pp.128-147 . In L . G . Higley and L .P .Pedigo (eds), Economic thresholds for integrated pest management. University of Nebraska Press, Lincoln .

[9] Costa AI, Queiroz ME, Neves AA, de Sousa FA, Zambolim L.( 2015 ). Determination of pesticides in lettuce using solid-liquid extraction with low temperature partitioning. Food Chem. 15;181:64-71.

[10] Hurtado C, Domínguez C, Pérez-Babace L, Cañameras N, Comas J, Bayona JM (2016). Estimate of uptake and translocation of emerging organic contaminants from irrigation water concentration in lettuce grown under controlled conditions. J Hazard Mater. 15;305:139-48. doi: 10.1016/j.jhazmat.2015.11.039.

[11] Rahman MA, Alam I, Kim YG, Ahn NY, Heo SH, Lee DG, Liu G, Lee BH.( 2015) . Screening for saltresponsive proteins in two contrasting alfalfa cultivars using a comparative proteome approach. Plant Physiol Biochem. 2015 Apr;89:112-22. doi: 10.1016/j.plaphy.2015.02.015.

[12] Siegwart M, Graillot B, Blachere Lopez C, Besse S, Bardin M, Nicot PC, Lopez-Ferber M.( 2015). Resistance to bio-insecticides or how to enhance their sustainability: a review. Front Plant Sci. 19;6:381. doi: 10.3389/fpls.2015.00381.

[13]Lichtenthaler, H.K. (1987). Chlorophylls and Carotenoids: Pigments of Photosynthetic Biomembrnes. Methods in Enzymology. 148, 350-382.

[14]E. W. Yemm and A. J. Willis ( 1954 ). The estimation of carbohydrates in plant extracts by anthrone. Biochem J.: 57(3): 508-514.

[15] Bates et al., (1973). Rapid determination of free proline for water-stress studies . Plant and Soil., Volume 39, Issue 1, pp 205-207.

[16]Haile,F.J., R.K.D.Peterson and L.G. Higley (1999) . Gas-exchange response of alfalfa and soybean treated with insecticides . J .Econ . Intomol .92:954-959 .

[17]Ferree, D.C.(1970) .Influence of pesticides on photosynthesis of crop plants, pp.331-341 . In. R 
.Marcelle, H . G .Clijsters and M . Van Poucke (eds), Photosynthesis and plant development. Junk, The Hague .

[18] Jones, V . P ., N . C .Toscano, M . W. Johnson, S .C . Welter, and R . R . Youngman ( 1986) . Pesticide effects on plant physiology : integration into a pest management program . Bull. Entomol . Soc . Am .32: 103-109.

[19] Moreby S .J ., Southway S ., Barker A . and Holland J . $M$. (2001) .A comparison of the effects of new and established insecticides on nontarget invertibrates of winter wheat fields . Environ. Toxicol. Chen .20 : 2243- 54

[20]Eckhardt, U., Grimm, B. and Hörtensteiner, S. (2004). Recent advances in chlorophyll biosynthesis and breakdown in higher plants. Plant Molecular Biology. $56,1-14$.

[21]Zhu Z, Chen J, Zheng HL.(2012). Physiological and proteomic characterization of salt tolerance in a mangrove plant, Bruguiera gymnorrhiza (L.) Lam. Tree Physiol. 2012 Nov;32(11):1378-88.

[22] Pinto MF, Fensterseifer IC, Migliolo L, Sousa DA, de Capdville G, Arboleda-Valencia JW, Colgrave ML, Craik DJ, Magalhães BS, Dias SC, Franco OL.( 2012 ). Identification and structural characterization of novel cyclotide with activity against an insect pest of sugar cane. J Biol Chem. 2012 Jan 2;287(1):134-47.

[23] AzaMax, and AzaGuard..( 2014 ). 6"TreeAzin Systemic Insecticide". BioForest Technologies. Retrieved . 06-03.

[24] PongtipSithsarn . Charlotte U. Clrlsen,Mongens L. Andersen,WandeeGritsanapan, and Leif $\mathrm{H}$ .Skibsted(2007). Antioxidative effects of leaves from Azadirachta species of different provenience .Food Chemistry, 104,1539-1549.

[25] Hossain MM and Richardson JR ( 2011 ) . Mechanism of pyrethoridpesticide - induced apoptosis : role of calpain and the ER stress pathway . Toxicol Sci . 122 (2) : $512-25$.

[26] Bacci, E., D. Calamari, C. Gaggi and M. Vighi. 1987. An approach for the prediction of environmental distribution and fate of cypermethrin. Chemosphere. 16(7):1373-1380.

[27] Scott-Dupree C . D, C .Ron Harris, M .L .Dugas and S Pirani (2008) . Situation of pyrethroids resistance in spiny bollworm . and carbaryl joint toxic effect RrsistantPest Management Newsletter, 17 (2) :38-42 .

[28]Fikru J. H. ; David, L. K . ; Jeese, M. R . and Leon, G. H. ( 2000 ) : Impact of insecticides and surfactant on lettuce physiology and yield . . J. Economic Entomology, 93 (3) : 788-794 